\title{
Constructed Wetlands: Treatment of Concentrated Storm Water Runoff (Part A)
}

\author{
Byoung-Hwa Lee, Miklas Scholz, , and Antje Horn \\ Institute for Infrastructure and Environment \\ School of Engineering and Electronics \\ The University of Edinburgh \\ Edinburgh EH9 3JL, Scotland \\ United Kingdom
}

\begin{abstract}
The aim of this research was to assess the treatment efficiencies for gully pot liquor of experimental vertical-flow constructed wetland filters containing Phragmites australis (Cav.) Trin. ex Steud. (common reed) and filter media of different adsorption capacities. Six out of 12 filters received inflow water spiked with metals. For 2 years, hydrated nickel and copper nitrate were added to sieved gully pot liquor to simulate contaminated primary treated storm runoff. For those six constructed wetland filters receiving heavy metals, an obvious breakthrough of dissolved nickel was recorded after road salting during the first winter. However, a breakthrough of nickel was not observed, since the inflow $\mathrm{pH}$ was raised to eight after the first year of operation. High $\mathrm{pH}$ facilitated the formation of particulate metal compounds such as nickel hydroxide. During the second year, reduction efficiencies of heavy metal, 5-days at $20^{\circ} \mathrm{C} \mathrm{N}$-Allylthiourea biochemical oxygen demand (BOD) and suspended solids (SS) improved considerably. Concentrations of BOD were frequently $<20 \mathrm{mg} / \mathrm{L}$. However, concentrations for SS were frequently $>30 \mathrm{mg} / \mathrm{L}$. These are the two international thresholds for secondary wastewater treatment. The BOD removal increased over time due to biomass maturation, and the increase of $\mathrm{pH}$. An analysis of the findings with case-based reasoning can be found in the corresponding follow-up paper (Part B).
\end{abstract}

Key words: storm runoff; gullies; constructed wetlands, biochemical oxygen demand; suspended solids; conductivity

\section{INTRODUCTION}

$\mathbf{C}$ Constructed wetlands in the United States and Europe are usually soil or gravel based horizontalflow systems planted with Typha latifolia L. (cattail) and/or Phagmites australis (Cav.) Trin. ex Steud. (com- mon reed). They are used to treat storm runoff, domestic and industrial wastewater (Cooper et al., 1996; Kadlec and Knight, 1996; Scholz, 2003), and have also been applied for passive treatment of mine wastewater drainage (Mungur et al., 1997; Mays and Edwards, 2001).

\footnotetext{
*Corresponding author: School of Engineering \& Electronics, College of Science \& Engineering, The University of Edinburgh, Faraday Building, The King's Bu, Edinburgh, EH9 3JL, Scotland. Phone: 44(0) 131650 6780; Fax: 44 (0) 1316506554 ; Email:m.scholz@ed.ac.uk
} 
Storm runoff from urban areas has been recognized as a major contributor to pollution of the receiving urban watercourses (Park and Yoon, 2003). The principal pollutants in urban runoff are 5-day at $20^{\circ} \mathrm{C} \mathrm{N}$-Allylthiourea [biochemical oxygen demand (BOD)], suspended solids (SS), heavy metals, deicing salts, hydrocarbons, and fecal coliforms (Scholz and Martin, 1998; Scholz and Zettel, 2004).

Although various conventional methods have been applied to treat storm water (Cooper et al., 1996; Park and Yoon, 2003), most technologies are not cost-effective or too complex. Constructed wetlands integrated into a best management practice concept are a sustainable means of treating storm water and proved to be more economical (e.g., construction and maintenance) and energy efficient than traditional centralized treatment systems (Kadlec et al., 2000). Furthermore, wetlands enhance biodiversity and are less susceptibile to variations of loading rates (Cooper et al., 1996; Scholz and Trepel, 2004).

Contrary to standard domestic wastewater treatment technologies, storm water (gully pot liquor and effluent) treatment systems have to be robust to highly variable flow rates and water quality variations. The storm water quality depends on the load of pollutants present on the road, and the corresponding dilution by each storm event (Park and Yoon, 2003; Scholz, 2003).

In contrast to standard horizontal-flow constructed treatment wetlands, vertical-flow wetlands are flat, intermittently flooded, and drained, allowing air to refill the soil pores within the bed (Cooper et al., 1996; Green et al., 1998; Gervin and Brix, 2001). When the wetland is dry, oxygen (as part of the air) can enter the top layer of debris and sand. The following flow of wastewater will absorb the gas and transport it to the anaerobic bottom of the wetland. Furthermore, aquatic plants such as macrophytes transport oxygen to the rhizosphere. However, this natural process of oxygen enrichment is not as effective as the previous engineering method (Kadlec and Knight, 1996; Karathanasis et al., 2003).

While it has been recognized that vertical-flow constructed wetlands usually have higher removal efficiencies with respect to organic pollutants and nutrients in comparison to horizontal-flow wetlands, denitrification is usually less efficient in vertical-flow systems (Luederits et al., 2001).

\section{Heavy metal removal}

Heavy metals within storm water are associated with fuel additives, car body corrosion, and tire and brake wear. Common metal pollutants from cars include copper, nickel, lead, zinc, chromium, and cadmium. Freshwater quality standards are most likely to be exceeded by copper (Cooper et al., 1996; Kadlec and Knight, 1996; Scholz et al., 2002; Tchobanoglous et al., 2003).

Metals occur in soluble, colloidal, or particulate forms. Heavy metals are most bioavailable when they are soluble, either in ionic or weakly complexed form (Cooper et al., 1996; Wood and Shelley, 1999; Cheng et al., 2002).

There have been many studies on the specific filter media within constructed wetlands to treat heavy metals economically, such as limestone, lignite, activated carbon, peat, and leaves (Scholz and Martin, 1998; Scholz et al., 2002). Metal bioavailability and reduction are controlled by chemical processes including acid volatile sulfide formation and organic carbon binding and sorption in reduced sediments of constructed wetlands (ObarskaPemkowiak and Klimkowska, 1999; Wood and Shelley, 1999; Kadlec, 2002). It follows that metals usually accumulate in the top layer (fine aggregates, sediment, and litter) of vertical-flow and near the inlet of horizontalflow constructed treatment wetlands (Cheng et al., 2002; Scholz and Xu, 2002; Vymazal and Krasa, 2003).

Physical and chemical properties of the wetland soil and aggregates affecting metal mobilization include particle size distribution (texture), redox potential, $\mathrm{pH}$, organic matter, salinity, and the presence of inorganic matter such as sulfides and carbonates (Backstrom et al., 2004).

The cation exchange capacity of maturing wetland soils and sediments tend to increase as texture becomes finer because more negatively charged binding sites are available. Organic matter has a relatively high proportion of negatively charged binding sites. Salinity and $\mathrm{pH}$ can influence the effectiveness of the cation exchange capacity of soils and sediments because the negatively charged binding sites will be occupied by a high number of sodium or hydrogen cations (Knight et al., 1999).

Sulfides and carbonates may combine with metals to form relatively insoluble compounds. Especially the formation of metal sulfide compounds may provide longterm heavy metal removal, because these sulfides will remain permanently in the wetland sediments as long as they are not reoxidized (Cooper et al., 1996; Kadlec and Knight, 1996).

\section{Project purpose}

The major purpose of this study is to improve the design, operation, and management of vertical-flow constructed treatment wetlands to secure a high wastewater treatment performance during all seasons. The objectives are to assess

1. the performance of vertical-flow constructed treatment wetland filters, combined with a treatment pond (above the litter zone) for gully pot liquor treatment; 


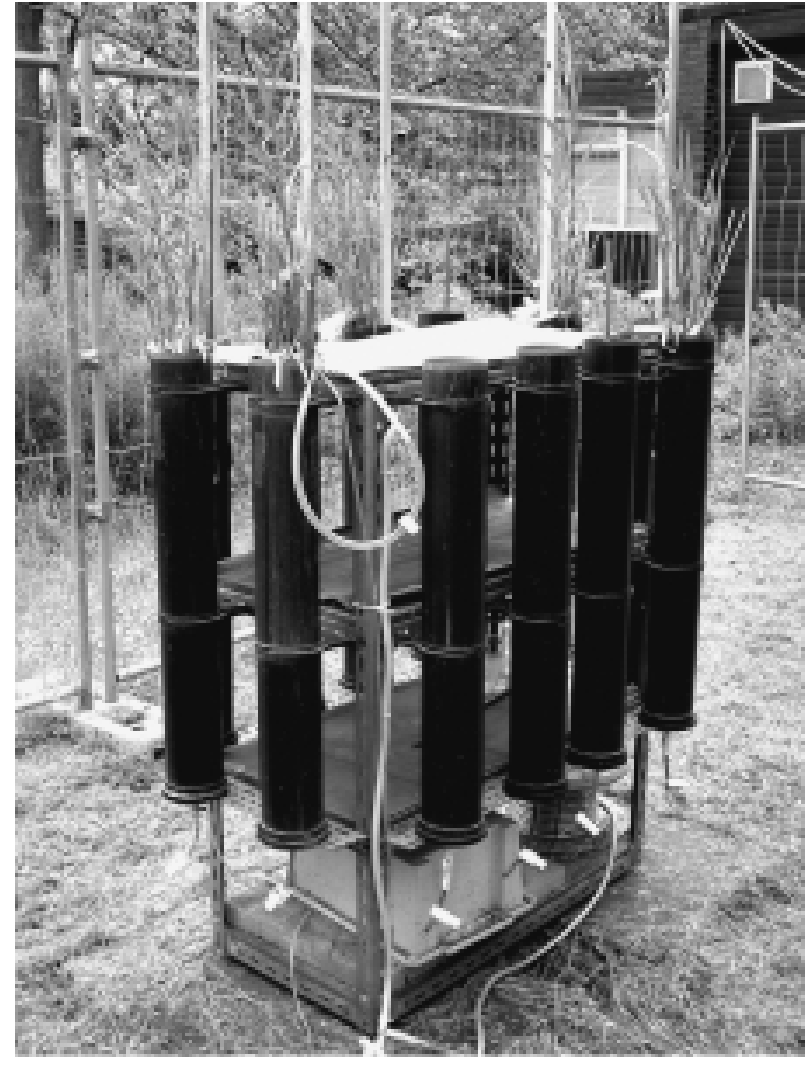

Figure 1. Constructed treatment wetland rig (The King's Buildings campus; The University of Edinburgh) in May 2004.

2. the compliance with water quality standards in terms of the reduction efficiencies of BOD, SS, nickel, copper, and nitrate;

3. the impact of environmental conditions, such as variations of salt concentrations, $\mathrm{pH}$, and the temperature on the treatment performance of constructed wetlands during all seasons;

4. the feasibility of conventional chemical $\mathrm{pH}$ adjustment to prevent heavy metal leaching during winter; and

5. the overall role of adsorption media and $P$. australis.

\section{EXPERIMENTAL PROTOCOLS}

\section{Study site}

Twelve wetland filters (Fig. 1) were located outdoors at The King's Buildings campus (The University of Edinburgh, Scotland) to assess the system performance in a cold climate (09/09/02 to 21/09/04). The 12 first days of operation were not analyzed because the water quality was not representative. Inflow water, polluted by road runoff, was collected from randomly selected gully pots on the campus, the nearby predominantly housing estates and two major roads. After mixing both the sediment and the water phase within the gully pot, water was collected by manual abstraction with a 2 -L beaker.

\section{Filter design, media composition, and limitations}

Round drainage pipes were used to construct the aboveground filters. All 12 vertical-flow wetland filters (Fig. 1) were designed with the following dimensions: height $=83 \mathrm{~cm}$ and diameter $=10 \mathrm{~cm}$. The relatively small size of these wetlands makes them vulnerable to environmental changes. However, a literature search has revealed that the use of small wetlands for experimental purposes is common to simulate industrial-scale systems, and that data variation is similar between small and large systems (Karathanasis et al., 2003; Scholz et al., 2002; Wießner et al., 2004; Zhao et al., 2004).

Aboveground filters experience higher temperatures and associated data variations than below-ground filters in summer. It follows that performance data might be "overly optimistic" for this season. However, aboveground filters are exposed to severe conditions such as relatively low temperatures in winter in comparison to below-ground systems that are insulated by the (frozen) soil, debris, litter, and potentially snow (Picard et al., 2004; Scholz and $\mathrm{Xu}, 2002)$. Moreover, the macrophytes and most of the microbial biomass are usually inactive during winter. Therefore, freezing and thawing events have little impact on the filtration performance (Cooper et al., 1996; Kadlec and Knight, 1996).

Different packing order arrangements of filter media and plant roots were used in the wetland filters (Tables

Table 1. Systematic and stratified experimental setup of filter content and operation.

\begin{tabular}{lccccc}
\hline Filter & Planted & Media $^{\mathrm{a}}$ & Metals $^{\mathrm{b}}$ & Aerated & Highloading $^{\mathrm{c}}$ \\
\hline 1 & No & 1 & No & No & No \\
2 & No & 1 & Yes & No & No \\
3 & No & 2 & No & No & No \\
4 & Yes & 2 & No & No & No \\
5 & No & 3 & No & No & No \\
6 & Yes & 3 & No & No & No \\
7 & No & 2 & Yes & No & No \\
8 & Yes & 2 & Yes & No & No \\
9 & No & 3 & Yes & No & No \\
10 & Yes & 3 & Yes & No & No \\
11 & Yes & 3 & Yes & Yes & No \\
12 & Yes & 3 & Yes & Yes & Yes \\
\hline
\end{tabular}

${ }^{\mathrm{a}} 1=$ no media, $2=$ standard, $3=$ addition of Filtralite (light expanded clay) and Frogmat (barley straw), see also Table 2; baddition of hydrated copper and nickel nitrate; ${ }^{c}$ Filter 12 received approximately $153 \%$ additional inflow in comparison to Filter 11 (Table 3), for example. 
1 and 2). The outlet of each constructed wetland comprised a valve at the bottom of each filter. In September 2002 , the calculated empty filter bed volumes were approximately $6.2,6.4,4.0,4.1,3.8,4.1,3.8,4.0,3.8,4.0$, 4.0, and $4.0 \mathrm{~L}$ for Filters 1 to 12, respectively. The filter volume capacities were measured by draining the filters entirely.

The inflow waters of Filter 2 and Filters 7 to 12 were dosed with hydrated copper nitrate $\left(\mathrm{Cu}\left(\mathrm{NO}_{3}\right)_{2} \cdot 3 \mathrm{H}_{2} \mathrm{O}\right)$ and hydrated nickel nitrate $\left(\mathrm{Ni}\left(\mathrm{NO}_{3}\right)_{2} \cdot 6 \mathrm{H}_{2} \mathrm{O}\right)$. Filters 1 and 2 (controls) are similar to wastewater stabilization ponds or gully pots (extended storage) without a significant amount of filter media (Table 2). In comparison, Filters 3, 5, 7, and 9 are similar to gravel and slow sand filters, and Filters 4, 6, 8, and 10 are typical reed bed filters. The reed bed filters contain gravel and sand substrate and native Phragmites australis (Cav.) Trin. ex Steud. (common reed), all of similar total biomass weight during planting and from the same local source. However, Filters 5, 6, 9, and 10 also contain adsorption media. Additional natural adsorption media (Filtralite and Frogmat) were used. Filtralite [containing 3\% of calcium oxide $(\mathrm{CaO})$ ] with diameters between 1.5 and $2.5 \mathrm{~mm}$ is associated with enhanced metal and nutrient reduction (Brix et al., 2001; Scholz and Xu, 2002). Furthermore, Frogmat (natural product based on raw barley straw) has a high adsorption area, and is therefore likely to be associated with a high heavy metal reduction potential. The use of other filter media with high adsorption capacities such as activated carbon (Scholz and Martin, 1998; Scholz et al., 2002) and oxide-coated sand (Sansalone, 1999) has been discussed elsewhere.

Filters 11 and 12 are more complex in their design and operation (Table 1). The top water layer of both filters is aerated (with air supplied by air pumps) to enhance oxidation (minimizing zones of reducing conditions) and nitrification (Green et al., 1998; ObarskaPempkowiak and Klimkowska, 1999; Cheng et al., 2002). Filter 12 receives about $153 \%$ of Filter 11's mean annual inflow volume and load (Table 1). The hydraulic regime of Filter 12 differs from that of Filters 1 to 11 to identify the best filtration performance. A higher hydraulic load should result in greater stress on $P$. australis and biomass.

Table 2. Packing order of vertical-flow wetland filters (F).

\begin{tabular}{|c|c|c|c|c|c|c|}
\hline $\begin{array}{c}\text { Height } \\
(\mathrm{cm})\end{array}$ & $F 1$ & $F 2$ & $F 3$ & $F 4$ & $F 5$ & F6 \\
\hline $61-83$ & W & W & $\mathrm{W}$ & W & W & W \\
\hline $56-60$ & W & W & 6 & $6+P$ & 7 & $7+P$ \\
\hline $51-55$ & W & W & 6 & $6+P$ & 6 & $6+P$ \\
\hline $36-50$ & W & W & 4 & $4+\mathrm{P}$ & 5 & $5+P$ \\
\hline $31-35$ & W & W & 3 & 3 & 5 & 5 \\
\hline $26-30$ & W & W & 3 & 3 & 4 & 4 \\
\hline $21-25$ & W & W & 2 & 2 & 3 & 3 \\
\hline $16-20$ & W & W & 2 & 2 & 2 & 2 \\
\hline $11-15$ & 2 & 2 & 2 & 2 & 2 & 2 \\
\hline $0-10$ & 1 & 1 & 1 & 1 & 1 & 1 \\
\hline $\begin{array}{l}\text { Height } \\
(\mathrm{cm})\end{array}$ & $F 7$ & $F 8$ & F9 & F10 & $F 11$ & $F 12$ \\
\hline $61-83$ & W & W & $\mathrm{W}$ & W & AW & AW \\
\hline $56-60$ & 6 & $6+P$ & 7 & $7+P$ & $7+P$ & $7+P$ \\
\hline $51-55$ & 6 & $6+P$ & 6 & $6+P$ & $6+P$ & $6+P$ \\
\hline $36-50$ & 4 & $4+P$ & 5 & $5+P$ & $5+\mathrm{P}$ & $5+P$ \\
\hline $31-35$ & 3 & 3 & 5 & 5 & 5 & 5 \\
\hline $26-30$ & 3 & 3 & 4 & 4 & 4 & 4 \\
\hline $21-25$ & 2 & 2 & 3 & 3 & 3 & 3 \\
\hline $16-20$ & 2 & 2 & 2 & 2 & 2 & 2 \\
\hline $11-15$ & 2 & 2 & 2 & 2 & 2 & 2 \\
\hline $0-10$ & 1 & 1 & 1 & 1 & 1 & 1 \\
\hline
\end{tabular}

Abbreviations: W, water, P, Phragmites australis (Cav.) Trin. ex Steud;. (common reed); AW, aerated water; 1, stones; 2, large gravel; 3, medium gravel; 4, small gravel; 5, Filtralite (light expanded clay product); 6, sand (0.6-1.2 mm); 7, Frogmat (barley straw). 


\section{Environmental conditions and operation}

The filtration system was designed to operate in batch flow mode to reduce pumping and computer control costs. All filters were periodically inundated with pretreated inflow gully pot liquor and drained to encourage air penetration through the aggregates (Cooper et al., 1996; Gervin and Brix, 2001; Scholz and Xu, 2002).

Since 22 September 2003, the pH value of the inflow has been artificially raised by addition of sodium hydroxide $(\mathrm{NaOH})$ to the sieved gully pot liquor to prevent a breakthrough of metals (see below and Tchobanoglous et al., 2003). It follows that the inflow $\mathrm{pH}$ was therefore increased from a mean $\mathrm{pH} 6.7$ to $\mathrm{pH} 8.1$ (Table 3).

\section{Metal nitrates}

Copper and nickel were selected as additional heavy metals for investigation because they are commonly occurring contaminants from road vehicles and are not easily bioavailable (Cooper et al., 1996; Kadlec and Knight, 1996; Scholz and Xu, 2002). It follows that these metals are likely to accumulate within the sediment and debris of constructed wetlands. As the buildup continues, metal toxicity increases as does the risk of severe pollution due to leaching (Scholz et al., 2002).

Some heavy metals do accumulate easily in constructed wetlands but may be released if environmental conditions change; for example, road gritting (containing

Table 3. Primary treated gully pot effluent: water quality variables after contamination with hydrated copper nitrate and hydrated nickel nitrate.

\begin{tabular}{|c|c|c|c|c|c|c|}
\hline \multicolumn{7}{|c|}{$22 / 09 / 02-21 / 09 / 03$} \\
\hline Variable & Unit & Number of samples & Mean & $S D^{\mathrm{a}}$ & Mean (winter) & Mean (summer) \\
\hline Nickel (dissolved) & $\mathrm{mg} / \mathrm{L}$ & 57 & 1.06 & 0.143 & 1.08 & 1.09 \\
\hline Copper (dissolved) & $\mathrm{mg} / \mathrm{L}$ & 58 & 1.03 & 0.036 & 1.04 & 1.02 \\
\hline $\mathrm{BOD}^{\mathrm{b}}$ & $\mathrm{mg} / \mathrm{L}$ & 58 & 61.1 & 49.29 & 43.8 & 86.9 \\
\hline Nitrate-nitrogen & $\mathrm{mg} / \mathrm{L}$ & 63 & 1.45 & 1.008 & 1.43 & 1.12 \\
\hline Ammonia-nitrogen & $\mathrm{mg} / \mathrm{L}$ & 63 & 1.65 & 2.058 & 1.72 & 2.11 \\
\hline Ortho-phosphate-phosphorus & $\mathrm{mg} / \mathrm{L}$ & 62 & 0.06 & 0.149 & 0.05 & 0.03 \\
\hline Suspended solilds & $\mathrm{mg} / \mathrm{L}$ & 70 & 335.7 & 377.75 & 743.7 & 160.7 \\
\hline Total solids & $\mathrm{mg} / \mathrm{L}$ & 66 & $2,995.5$ & $6,793.27$ & $9,403.9$ & 376.5 \\
\hline Turbidity & NTU & 71 & 311.7 & 479.65 & 690.6 & 162.1 \\
\hline Dissolved oxygen & $\mathrm{mg} / \mathrm{L}$ & 68 & 4.70 & 2.493 & 5.70 & 3.16 \\
\hline $\mathrm{pH}$ & - & 71 & 6.69 & 0.411 & 6.89 & 6.72 \\
\hline Redox potential & $\mathrm{mV}$ & 62 & 142.5 & 112.72 & 165.5 & 2.7 \\
\hline Conductivity & $\mu \mathrm{S}$ & 71 & $5,139.1$ & $11,182.22$ & $15,311.6$ & 501.0 \\
\hline Temperature (air) & ${ }^{\circ} \mathrm{C}$ & 70 & 12.3 & 5.96 & 7.2 & 17.9 \\
\hline Temperature (gully pot) & ${ }^{\circ} \mathrm{C}$ & 69 & 10.7 & 5.78 & 4.8 & 18.0 \\
\hline \multicolumn{7}{|c|}{ 22/09/03-21/09/04 (artificial increase of pH after 21/09/03) } \\
\hline Variable & Unit & Number of samples & Mean & $S D^{\mathrm{a}}$ & Mean (winter) & Mean (summer) \\
\hline Nickel (dissolved) & $\mathrm{mg} / \mathrm{L}$ & 68 & 1.02 & 0.042 & 1.01 & 1.02 \\
\hline Copper (dissolved) & $\mathrm{mg} / \mathrm{L}$ & 66 & 1.02 & 0.018 & 1.01 & 1.02 \\
\hline $\mathrm{BOD}^{\mathrm{b}}$ & $\mathrm{mg} / \mathrm{L}$ & 73 & 89.2 & 55.5 & 89.7 & 66.6 \\
\hline Nitrate-nitrogen & $\mathrm{mg} / \mathrm{L}$ & 72 & 1.38 & 1.220 & 1.19 & 1.14 \\
\hline Ammonia-nitrogen & $\mathrm{mg} / \mathrm{L}$ & 72 & 1.45 & 1.934 & 1.89 & 1.35 \\
\hline Ortho-phosphate-phosphorus & $\mathrm{mg} / \mathrm{L}$ & 72 & 0.10 & 0.136 & 0.07 & 0.16 \\
\hline Suspended solids & $\mathrm{mg} / \mathrm{L}$ & 75 & 853.9 & $1,420.85$ & $1,955.2$ & 366.7 \\
\hline Total solids & $\mathrm{mg} / \mathrm{L}$ & 71 & $2,141.8$ & $3,219.84$ & $5,296.4$ & 794.7 \\
\hline Turbidity & NTU & 78 & 274.5 & 358.57 & 546.2 & 143.6 \\
\hline Dissolved oxygen & $\mathrm{mg} / \mathrm{L}$ & 78 & 3.07 & 1.49 & 3.41 & 3.22 \\
\hline $\mathrm{pH}$ & - & 78 & 8.07 & 1.082 & 8.25 & 8.73 \\
\hline Redox potential & $\mathrm{mV}$ & 78 & 44.4 & 93.44 & 31.8 & 64.1 \\
\hline Conductivity & $\mu \mathrm{S}$ & 78 & $2,227.2$ & $4,620.82$ & $6,191.7$ & 403.6 \\
\hline Temperature (air) & ${ }^{\circ} \mathrm{C}$ & 155 & 13.7 & 6.46 & 7.1 & 20.6 \\
\hline Temperature (gully pot) & ${ }^{\circ} \mathrm{C}$ & 75 & 12.0 & 5.65 & 6.0 & 18.9 \\
\hline
\end{tabular}

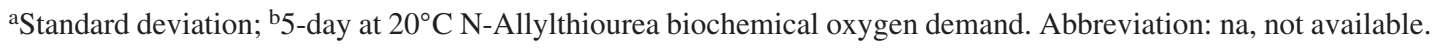


Table 4. Mean and standard deviation of outflow water quality variables.

\begin{tabular}{|c|c|c|c|c|c|c|c|}
\hline \multicolumn{8}{|c|}{ Mean $(22 / 09 / 02-21 / 09 / 03)$} \\
\hline Variable & Unit & Filter 1 & Filter 2 & Filter 3 & Filter 4 & Filter 5 & Filter 6 \\
\hline $\mathrm{BOD}^{\mathrm{a}}$ & $\mathrm{mg} / \mathrm{L}$ & 37.2 & 43.4 & 16.4 & 30.7 & 23.3 & 33.5 \\
\hline Suspended solids & $\mathrm{mg} / \mathrm{L}$ & 174.6 & 189.0 & 120.8 & 130.4 & 132.4 & 127.3 \\
\hline Total solids & $\mathrm{mg} / \mathrm{L}$ & $2,772.8$ & $3,602.5$ & 2938.7 & 3.266 .2 & $2,949.1$ & $3,990.4$ \\
\hline Turbidity & NTU & 79.8 & 89.0 & 15.0 & 39.0 & 35.4 & 25.6 \\
\hline Conductivity & $\mu \mathrm{S}$ & $5,148.5$ & $6,827.7$ & $5,920.8$ & $5,392.6$ & $5,809.9$ & $5,797.7$ \\
\hline Variable & Unit & Filter 7 & Filter 8 & Filter 9 & Filter 10 & Filter 11 & Filter 12 \\
\hline $\mathrm{BOD}^{\mathrm{a}}$ & $\mathrm{mg} / \mathrm{L}$ & 12.7 & 22.0 & 21.8 & 37.6 & 20.1 & 19.8 \\
\hline Suspended solids & $\mathrm{mg} / \mathrm{L}$ & 96.7 & 92.5 & 85.8 & 79.1 & 73.2 & 163.5 \\
\hline Total solids & $\mathrm{mg} / \mathrm{L}$ & $2,375.6$ & $2,118.4$ & $1,717.1$ & $1,808.8$ & $1,779.0$ & $2,941.7$ \\
\hline Turbidity & NTU & 11.2 & 20.6 & 27.3 & 34.3 & 17.5 & 43.5 \\
\hline Conductivity & $\mu \mathrm{S}$ & $4,912.2$ & $4,346.8$ & $3,808.8$ & $3,667.8$ & $3,528.5$ & $5,941.4$ \\
\hline \multicolumn{8}{|c|}{ Mean (22/09/03-21/09/0404; artificial increase of pH after 21/09/03) } \\
\hline Variable & Unit & Filter 1 & Filter 2 & Filter 3 & Filter 4 & Filter 5 & Filter 6 \\
\hline $\mathrm{BOD}^{\mathrm{a}}$ & $\mathrm{mg} / \mathrm{L}$ & 30.2 & 30.4 & 3.1 & 2.3 & 4.4 & 4.4 \\
\hline Suspended solids & $\mathrm{mg} / \mathrm{L}$ & 434.6 & 9.07 .5 & 76.6 & 65.8 & 130.4 & 82.7 \\
\hline Total solids & $\mathrm{mg} / \mathrm{L}$ & $1,690.3$ & $1,931.8$ & $1,379.6$ & $1,398.9$ & $1,372.9$ & $1,430.7$ \\
\hline Turbidity & NTU & 118.6 & 117.8 & 6.0 & 4.8 & 8.6 & 6.0 \\
\hline Conductivity & $\mu \mathrm{S}$ & $2,268.2$ & $2,356.0$ & $2,339.9$ & $2,260.3$ & $2,220.0$ & $2,507.6$ \\
\hline Variable & Unit & Filter 7 & Filter 8 & Filter 9 & Filter 10 & Filter 11 & Filter 12 \\
\hline $\mathrm{BOD}^{\mathrm{a}}$ & $\mathrm{mg} / \mathrm{L}$ & 2.3 & 2.7 & 2.8 & 3.5 & 3.6 & 7.6 \\
\hline Suspended solids & $\mathrm{mg} / \mathrm{L}$ & 147.3 & 78.1 & 83.4 & 71.7 & 89.9 & 102.8 \\
\hline Total solids & $\mathrm{mg} / \mathrm{L}$ & $1,390.3$ & $1,497.3$ & $1,509.4$ & $1,804.7$ & $1,578.5$ & $1,647.4$ \\
\hline Turbidity & NTU & 9.6 & 6.9 & 10.2 & 4.9 & 7.4 & 20.1 \\
\hline Conductivity & $\mu \mathrm{S}$ & $2,199.2$ & $2,484.2$ & $2,450.6$ & $2,459.6$ & $2,534.5$ & $2,495.3$ \\
\hline \multicolumn{8}{|c|}{ Standard deviation (22/09/02-21/09/03) } \\
\hline Variable & Unit & Filter 1 & Filter 2 & Filter 3 & Filter 4 & Filter 5 & Filter 6 \\
\hline $\mathrm{BOD}^{\mathrm{a}}$ & $\mathrm{mg} / \mathrm{L}$ & 39.89 & 41.95 & 13.09 & 31.24 & 22.74 & 30.33 \\
\hline Suspended solids & $\mathrm{mg} / \mathrm{L}$ & 365.53 & 440.59 & 265.83 & 252.75 & 249.34 & 273.44 \\
\hline Total solids & $\mathrm{mg} / \mathrm{L}$ & $7,273.37$ & $10,821.20$ & $6,886.58$ & $6,585.16$ & $6,216.36$ & $8,318.42$ \\
\hline Turbidity & NTU & 96.15 & 73.83 & 24.21 & 61.19 & 46.64 & 28.45 \\
\hline Conductivity & $\mu \mathrm{S}$ & $13,473.42$ & $19,920.19$ & $13,442.84$ & $11,789.78$ & $12,286.69$ & $12,860.16$ \\
\hline Variable & Unit & Filter 7 & Filter 8 & Filter 9 & Filter 10 & Filter 11 & Filter 12 \\
\hline $\mathrm{BOD}^{\mathrm{a}}$ & $\mathrm{mg} / \mathrm{L}$ & 13.88 & 25.03 & 20.08 & 35.76 & 14.04 & 17.63 \\
\hline Suspended solids & $\mathrm{mg} / \mathrm{L}$ & 225.06 & 197.81 & 168.08 & 166.03 & 144.40 & 307.73 \\
\hline Total solids & $\mathrm{mg} / \mathrm{L}$ & $5,948.07$ & $4,720.47$ & $3,580.56$ & $3,648.16$ & $3,659.61$ & $6,450.13$ \\
\hline Turbidity & NTU & 18.95 & 30.18 & 42.51 & 54.91 & 18.07 & 86.23 \\
\hline Conductivity & $\mu \mathrm{S}$ & $11,672.86$ & 9.431 .98 & $6,319.37$ & $6,683.83$ & $7,077.11$ & $11,479.77$ \\
\hline
\end{tabular}


Table 4. Mean and standard deviation of outflow water quality variables. (CONTINUED)

\begin{tabular}{|c|c|c|c|c|c|c|c|}
\hline Variable & Unit & Filter 1 & Filter 2 & Filter 3 & Filter 4 & Filter 5 & Filter 6 \\
\hline $\mathrm{BOD}^{\mathrm{a}}$ & $\mathrm{mg} / \mathrm{L}$ & 21.24 & 37.06 & 7.23 & 3.11 & 8.11 & 6.66 \\
\hline Suspended solids & $\mathrm{mg} / \mathrm{L}$ & 449.80 & $3,580.34$ & 96.29 & 79.97 & 263.65 & 107.28 \\
\hline Total solids & $\mathrm{mg} / \mathrm{L}$ & $1,507.80$ & $2,417.22$ & $1,722.92$ & $1,601.87$ & $1,445.83$ & $1,714.86$ \\
\hline Turbidity & NTU & 90.33 & 258.22 & 6.89 & 4.44 & 8.38 & 4.48 \\
\hline Conductivity & $\mu \mathrm{S}$ & $2,945.92$ & $3,000.52$ & $2,839.88$ & $2,565.04$ & $2,476.56$ & $2,857.82$ \\
\hline Variable & Unit & Filter 7 & Filter 8 & Filter 9 & Filter 10 & Filter 11 & Filter 12 \\
\hline $\mathrm{BOD}^{\mathrm{a}}$ & $\mathrm{mg} / \mathrm{L}$ & 3.86 & 3.83 & 4.00 & 4.49 & 4.24 & 7.83 \\
\hline Suspended solids & $\mathrm{mg} / \mathrm{L}$ & 228.84 & 82.75 & 96.24 & 86.77 & 133.64 & 138.81 \\
\hline Total solids & $\mathrm{mg} / \mathrm{L}$ & $1,623.29$ & $1,538.09$ & $1,716.03$ & $2,553.49$ & $1,905.64$ & $2,426.29$ \\
\hline Turbidity & NTU & 18.79 & 7.76 & 19.59 & 4.24 & 10.94 & 37.18 \\
\hline Conductivity & $\mu \mathrm{S}$ & $2,611.49$ & $2,572.43$ & $2,840.91$ & $2,741.12$ & $3,069.47$ & $3,638.43$ \\
\hline
\end{tabular}

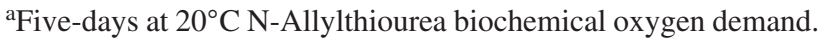

salt) in winter. Such transformation processes are not well understood (Norrstrom and Jacks, 1998).

Copper nitrate and nickel nitrate were added to the inflow water of Filter 2 and Filters 7 to 12 to give total concentrations of dissolved copper and nickel of approximately $1 \mathrm{mg} / \mathrm{L}$ for each metal, comparable to figures reported for urban water heavily contaminated with heavy metals and mine wastewater (Cooper et al., 1996; Kadlec and Knight, 1996; Mungur et al., 1997; Scholz and $\mathrm{Xu}, 2002$ ).

Concerning the dosed inflow water, the background concentration for nitrate-nitrogen (including nitrite-nitrogen) was only approximately $0.497 \mathrm{mg} / \mathrm{L}$. Therefore, introduced nitrate-nitrogen contributed to $65 \%$ (or approximately $0.917 \mathrm{mg} / \mathrm{L}$ ) of the overall nitrate-nitrogen (including nitrite-nitrogen) load.

The filter volumes available for influent water differ among the filters due to different filter media compositions (Table 2) and hydraulic regimes (Table 1). The mean annual total loading rates for the contaminated filters were therefore between 96 and $187 \mathrm{mg}$ for each metal.

\section{Metal determinations}

Metal concentrations were determined in the raw gully pot liquor, sieved (pore size of $0.25 \mathrm{~mm}$ ) gully pot liquor (partially used as actual inflow water for some filters), contaminated (added metal nitrates) sieved gully pot liquor (partially used as actual inflow water for some filters) and the outflow waters from the experimental rig (Table 1). Raw gully pot liquor was sieved to simulate preliminary and primary treated storm water. This procedure is in line with common practice in the wastewater industry (Cooper et al., 1996; Tchobanoglous et al., 2003).
A Varian Spectr AA 400 Atomic Absorption Spectrometer with a GTA-96 graphite furnace tube atomizer was used for the standard analysis of nickel and copper. Notched GTA partition tubes (coated) were applied, and the carrier gas was argon.

\section{$B O D$, nutrient, and other determinations}

The BOD was determined in all water samples with the OxiTop IS 12-6 system, a manometric measurement device, supplied by the Wissenschaftlich-Technische Werkstätten (WTW), Weilheim, Germany. Nitrification was suppressed by adding $0.05 \mathrm{~mL}$ of $5 \mathrm{~g} / \mathrm{L} \mathrm{N}$-Allylthiourea (WTW Chemical Solution No. NTH 600) solution per $50 \mathrm{~mL}$ of sample water.

Nitrate was reduced to nitrite by cadmium and determined as an azo dye at $540 \mathrm{~nm}$ (using a Perstorp Analytical EnviroFlow 3000 flow injection analyzer) following diazotization with sulfanilamide and subsequent coupling with N-1-naphthylethylendiamine dihydrocloride (Allen, 1974).

Ammonia-nitrate and ortho-phosphate-phosphorus were determined by automated colorimetry in all water samples from reaction with hypochlorite and salicylate ions in solution in the presence of sodium nitrosopentacyanoferrate (nitroprusside), and reaction with acidic molybdate to form a phosphomolybdenum blue complex, respectively (Allen, 1974). The colored complexes formed were measured spectrometrically at 655 and $882 \mathrm{~nm}$, respectively, using a Bran and Luebbe autoanalyzer (Model AAIII).

Composite water samples were analyzed on Mondays, Wednesdays, and Fridays. All other analytical procedures were performed according to the American standard methods (1995). 


\section{EXPERIMENTAL RESULTS AND DISCUSSION}

\section{Inflow water quality}

Table 3 summarizes the water quality of the inflow to those filters artificially contaminated with heavy metals after the first and second year of operation. The $\mathrm{pH}$ of the inflow was artificially raised to assess its influence on the treatment performance and particularly on the potential breakthrough of heavy metals during the second winter (Table 3).

Raw gully pot liquor was sieved (pore size of $2.5 \mathrm{~mm}$ ) to simulate preliminary treatment (Tchobanoglous et al., 2003). Sieving resulted in a mean annual reduction of BOD and SS by approximately 12 and 22\%, respectively.

The inflow data set was divided into two subsets (winter and summer) to assess the effect of seasonal variations (e.g., temperature) and road management (e.g., road gritting and salting) on the water quality. Most variables including BOD (except for the first year of operation), SS, total solids (TS), turbidity, and conductivity are high in winter compared to summer (Table 3).

\section{Comparison of annual outflow water qualities}

The overall filtration performance figures are summarized in Tables 4 and 5. Figure 2 shows selected inflow and selected outflow concentrations for nickel and copper. Concerning BOD removal, the performances of all filters (except for Filters 1 and 2; extended storage) improved greatly over time. The reductions in BOD were also satisfactory for most filters if compared to minimum American and European standards $(<20 \mathrm{mg} / \mathrm{L})$ for the secondary treatment of effluent (Tables 3 to 5).

Furthermore, the artificial increase of $\mathrm{pH}$ after the first year of operation had no apparent influence on the treatment performance of BOD. There is no obvious difference in performance between Filters 8 and 11, indicating that aeration did not contribute significantly to the removal of BOD (Tables 3 and 4).

Negative reduction rates for TS and conductivity were predominantly caused by road salting in late autumn and winter. Any conventional filter system including constructed wetlands is unable to retain salts in high concentrations. Therefore, salts cannot be retained after a certain loading threshold that is associated with a lag period is exceeded. The lag period is predominantly a function of the buffering capacity of the biomass and the batchflow operational mode (see above). It follows that after an initial positive removal period, the removal efficiencies are becoming negative (Norrstrom and Jacks, 1998). Furthermore, the dissolved solids fraction increases as microbial biomass mineralizes the organic contaminants.
Conductivity correlates well with dissolved solids that contribute to a large proportion of the TS mass (Cooper et al., 1996; Scholz et al., 2002).

In contrast to previous researchers who reported the worst seasonal performance for BOD removal during winter (Karathanasis et al., 2003), all filters with the exception of Filters 1 and 2 showed high BOD removal figures $(>94 \%)$ in the second winter. This suggests that soil microbes still have the capacity to decompose organic matter in winter.

Concerning other variables, reduction rates for SS increased also in the second year although outflow concentrations frequently exceeded the threshold of $30 \mathrm{mg} / \mathrm{L}$ throughout the year except for summer. Turbidity values of the outflow decreased greatly over time. Despite the artificial increase of $\mathrm{pH}$ in the inflow, the $\mathrm{pH}$ of the outflow was approximately neutral and comparable to the first year of operation. Moreover, the $\mathrm{pH}$ of the outflow was relatively stable in the second year (standard deviation of approximately 0.18 ).

\section{Heavy metal treatment}

Heavy metal removal efficiencies improved during the second year of operation (Fig. 2). However, the reduction in metals was not sufficient to comply with American standards for secondary wastewater treatment. Dissolved nickel and dissolved copper concentrations should not exceed $0.0071,0.0049 \mathrm{mg} / \mathrm{L}$, respectively (Tchobanoglous et al., 2003).

The decomposition of aquatic plants after fall, reducing soil conditions, road gritting, and salting during periods of low temperatures and acid rain contribute to increases of metal concentrations in the outflow (Norrstrom and Jacks, 1998; Sasaki et al., 2003). For example, high levels of conductivity were recorded in the filter inflow and outflows (Tables 3 to 5), and the breakthrough of dissolved nickel was observed during the first winter (Fig. 2a).

Concerning the effect of retention time on the treatment efficiency of metals, the heavy metal outflow concentrations of Filter 12 (higher loading rate) were slightly higher than the corresponding concentrations for the other filters. According to previous studies (Kadlec and Knight, 1996; Wood and Shelley, 1999), metal removal efficiencies for wetlands are highly correlated with influent concentrations and mass loading rates. Moreover, it was suggested that the formation of metal sulfides was favored in wetlands with long retention times. This may lead to a more sustainable management of constructed treatment wetlands.

\section{Link between $\mathrm{pH}$ and treatment of metals}

After the increase of the inflow $\mathrm{pH}$, mean reduction efficiencies for nickel increased during the second win- 


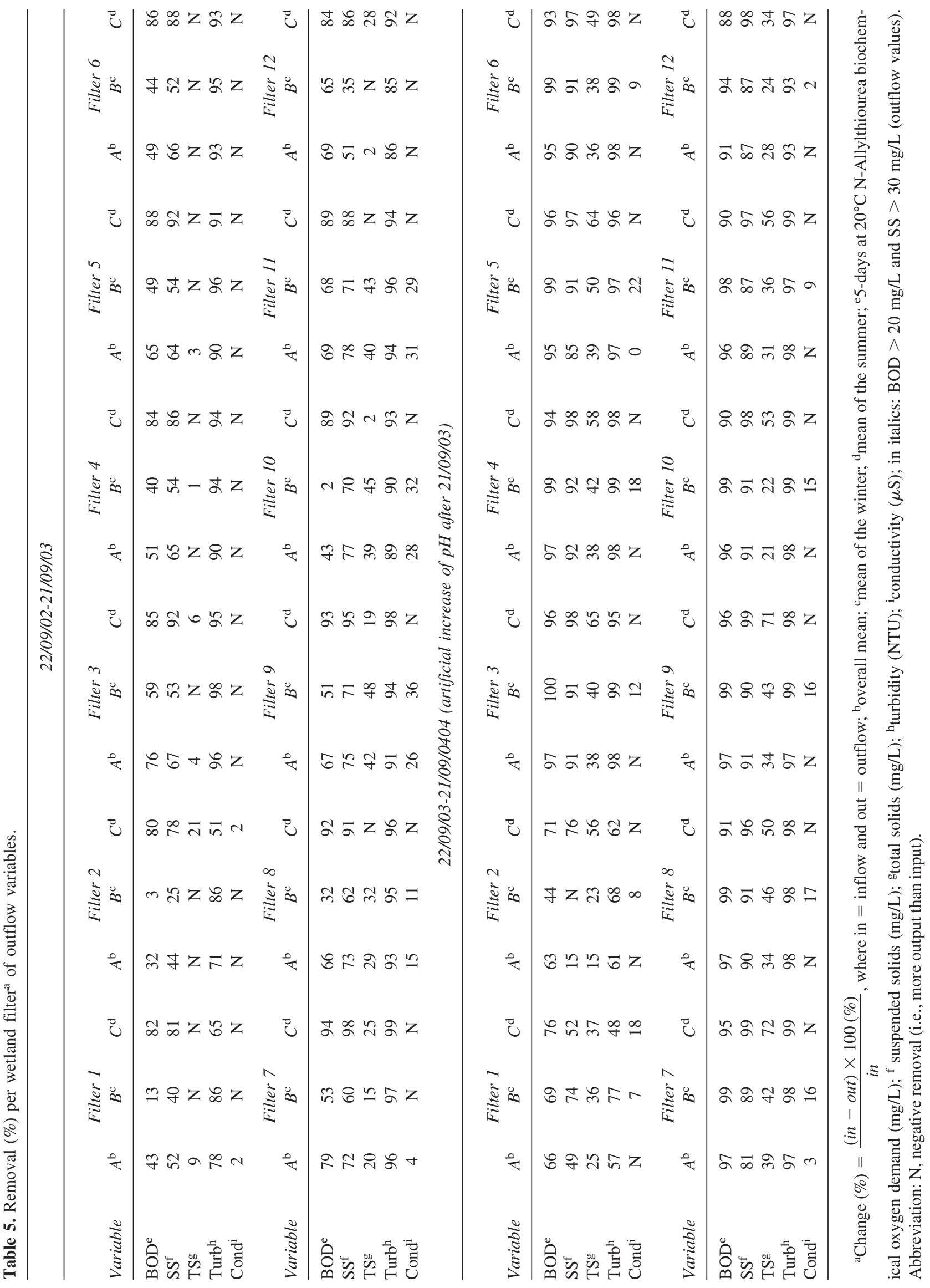



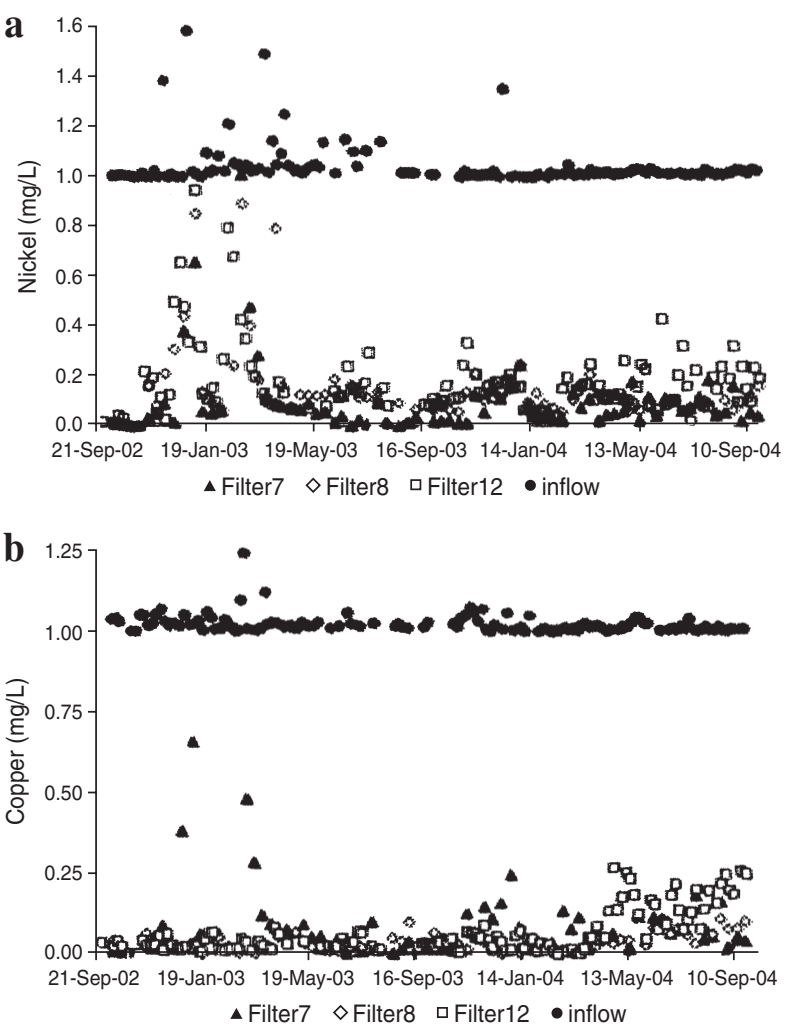

Figure 2. Daily (a) nickel and (b) copper concentrations $(\mathrm{mg} / \mathrm{L})$ in the inflow and outflows of Filters 7 (unplanted), 8 (planted), and 12 (planted and high loading).

ter compared to the first winter; for example, 90 and $65 \%$, respectively, for Filter 7 (Fig. 2a). Moreover, an obvious breakthrough of nickel was not observed during the second winter despite the presence of high salt concentrations in the inflow. This is likely to be due to the artificial increase of $\mathrm{pH}$. A high $\mathrm{pH}$ facilitates nickel precipitation. For example, nickel hydroxide $\left(\mathrm{Ni}(\mathrm{OH})_{2}\right)$ may precipitate at $\mathrm{pH} 9.1$ if the corresponding metal concentration is $1 \mathrm{mg} / \mathrm{L}$ (Tchobanoglous et al., 2003), which is similar to the inflow concentrations of spiked filters. Moreover, dissolved copper did not break through any constructed wetland filters throughout the study (Fig. 2b).

All filters acted as $\mathrm{pH}$ buffers after $\mathrm{pH}$ increase, and $\mathrm{pH}$ levels were subsequently reduced. It can be assumed that this buffering capacity is greatly enhanced by the presence of active biomass rather than macrophytes (Kadlec and Knight, 1996; Sasaki et al., 2003). However, the outflow $\mathrm{pH}$ values for the planted filters recorded were slightly lower than those for the unplanted filters. For example, the overall mean $\mathrm{pH}$ value for Filter 7 (unplanted filters) is 7.31, and the corresponding value for Filter 8 (planted filters) is 6.98 during the second year of operation.
Analysis of variance and case-based reasoning

An analysis of variance has shown that all filters containing aggregates are relatively similar to each other with respect to most of their outflow variables. It follows that some filters could be considered as replicates (e.g., Filter 7 is a replicate of Filter 3 ) despite the differences in filter setup (Tables 1 and 2). The $p$-values of the pairs for Filter 3 and 7 are 0.20, 0.95, and 0.98 for BOD, SS, and turbidity, respectively. Pairs of data associated with $p \geq 0.05$ can be regarded as statistically similar.

The absence of filter replicates is not a serious issue considering that the filter performances are similar (see above), and that the standard deviations (Table 4) of most outflow variables are comparable with large-scale systems (Cooper et al., 1996; Kadlec and Knight, 1996; Vymazal, 2002; Karathanasis et al., 2003). Moreover, a more detailed experimental study with three replicate filters, for example, would not be justified in terms of costs and potential scientific benefit.

Furthermore, case-based reasoning of the experimental data set has been applied by Lee et al. (2005). The purpose of this follow-up paper is to show how case-based reasoning can be applied for water quality control purposes.

\section{CONCLUSIONS}

Despite the highly variable water quality of road runoff, the novel filters showed great treatment performances particularly with respect to the 5-day at $20^{\circ} \mathrm{C} \mathrm{N}$-Allylthiourea biochemical oxygen demand (BOD) reduction in a cold climate. Removal efficiencies for SS in particular improved over time and dissolved copper was removed satisfactorily in comparison to values obtained from the literature. However, a breakthrough of dissolved nickel during the first winter of the first year of operation was observed. After creating an artificially high inflow $\mathrm{pH}$ of approximately 8 after 1 year of operation, nickel was successfully treated despite vulnerability to leaching when exposed to a high salt concentration during the second winter.

A high $\mathrm{pH}$ was apparently also linked to high removal efficiencies. The elevated $\mathrm{pH}$ had no apparent negative effect on the biomass including macrophytes. Moreover, filters showed a great $\mathrm{pH}$ buffering capacity. Findings indicate that conventional $\mathrm{pH}$ adjustment can be successfully applied to constructed wetland systems for storm water treatment.

The presence of Filtralite (adsorption filter media) and Phragmites australis (Cav.) Trin. ex Steud., common reed (macrophyte), did not result in an obvious reduction of metal concentrations in outflow waters. Operational conditions such as inflow $\mathrm{pH}$ and retention time were more important for the heavy metal treatment. 


\section{ACKNOWLEDGMENTS}

The authors acknowledge support provided by Ms. M. Wagner, Ms. S. Guilbert, Mr. F. McGowan, Dr P. Anderson, and Dr. K. Heal. Sponsors: The University of Edinburgh; The Royal Academy of Engineering; Optiroc Group AB; Frogmat International Holdings Ltd.

\section{REFERENCES}

ALLEN, S.E. (1974). Chemical Analysis of Ecological Materials. Oxford, UK: Blackwell.

AMERICAN PUBLIC HEALTH ASSOCIATION (APHA). (1995). Standard Methods for the Examination of Water and Wastewater, 19th ed. Washington, DC: Author.

BACKSTROM, M., KARLSSON, S., BACKMAN, L., FOLKESON, L., and LIND, B. (2004). Mobilisation of heavy metal by de-icing salts in a roadside environment. Water Res. 38, 720-732

BRIX, H., ARIAS, C.A., and DEL BUBBA, M. (2001). Media selection for sustainable phosphorus reduction in subsurface flow constructed wetlands. Water Sci. Technol. 44, 47-54.

CHENG, S.P., GROSSE, W., KARRENBROCK, F., and THOENNESSEN, M. (2002). Efficiency of constructed wetlands in decontamination of water polluted by heavy metals. Ecol. Eng. 18, 317-325.

COOPER, P.F., JOB, G.D., GREEN, M.B., and SHUTES, R.B. E. (1996). Reed Beds and Constructed Wetlands for Wastewater Treatment. Swindon, UK: WRc plc.

GERVIN, L., and BRIX, H. (2001). Reduction of nutrients from combined sewer overflows and lake water in a vertical-flow constructed wetland system. Water Sci. Technol. 44, 171-176.

GREEN, M., FRIEDLER, E., and SAFRAI, I. (1998). Enhancing nitrification in vertical-flow constructed wetlands utilizing a passive air pump. Water Res. 32, 3513-3520.

KADLEC, R.H. (2002). Effects of Pollutant Speciation in Treatment Wetlands Design. Chelsea, MI: Wetland Management Services.

KADLEC, R.H., and KNIGHT, R.L. (1996). Treatment Wetlands. Boca Raton, FL: CRC Press.

KADLEC, R., KNIGHT, R.L., VYMAZAL, J., BRIX, H., COOPER, P.F., and HABERL, R. (2000). Constructed Wetlands for Pollution Control. Scientific and Technical Report Number 8. International Water Association (IWA) Specialist Group "Use of Macrophytes for Water Pollution Control." London, UK: IWA Publishing.

KARATHANASIS, A.D., POTTER, C.L., and COYNE, M.S. (2003). Vegetation effects on fecal bacteria, BOD and suspended solids removal in constructed wetlands treating domestic wastewater. Ecol. Eng. 20, 157-169.
KNIGHT, R.L., KADLEC, R.H., and OHLENDORF, H.M. (1999). The use of treatment wetlands for petroleum industry effluents. Environ. Sci. Technol. 33, 973-980.

LEE, B.-H., SCHOLZ, M., HORN, A., and FURBER, A. 2005. Constructed wetlands: prediction of performance with casebased reasoning (Part B). Environ. Eng. Sci.

LUEDERITS, V., ECKERT, E., LANGE-WEBER, M., and LANGE A. (2001). Nutrient removal efficiency and resource economics of vertical flow and horizontal flow constructed wetlands. Ecol. Eng. 18, 157-171.

MAYS, P.A., and EDWARDS, G.S. (2001). Comparison of heavy metal accumulation in a natural wetland and constructed wetland receiving acid mine drainage. Ecol. Eng. 16, 487-500.

MUNGUR, A.S., SHUTES, R.B.E., REVITT, D.M., and HOUSE, M.A. (1997). An assessment of metal reduction by laboratory-scale wetland. Water Sci. Technol. 35, 125-133.

NORRSTROM, A.C., and JACKS, G. (1998). Concentration and fractionation of heavy metals in roadside soils receiving de-icing salts. Sci. Total Environ. 218, 161-174.

OBARSKA-PEMPKOWIAK, H., and KLIMKOWSKA, K. (1999). Distribution of nutrients and heavy metals in a constructed wetland system. Chemoshere 39, 303-312.

PARK, S.J., and YOON, T.I. (2003). Weighted coagulation with glass and diatomite for storm water treatment and sludge disposal. Environ. Eng. Sci. 20, 307-317.

PICARD, C.R., FRASER, L.H., and STEER, D. (2004). The interacting effects of temperature and plant community type on nutrient removal in wetland microcosms. Bioresource Technol. 96, 1039-1047.

SANSALONE, J.J. (1999). Adsorptive infiltration of metals in urban drainage-Media characteristics. Sci. Total Environ. 235, 179-188.

SASAKI, K., OGINO, T., ENDO, Y., and KUROSAWA, K. (2003). Field studies on heavy metal accumulation in a natural wetland receiving acid mine drainage. Mater. Trans. 44, 1877-1884.

SCHOLZ, M. (2003). Case study: Design, operation, maintenance and water quality management of sustainable storm water ponds for roof runoff. Bioresource Technol. 95, 269-279.

SCHOLZ, M., and MARTIN, R.J. (1998). Control of bio-regenerated granular activated carbon by spreadsheet modeling. J. Chem. Tech. Biotechnol. 71, 253-261.

SCHOLZ, M., and TREPEL, M. (2004). Water quality characteristics of vegetated groundwater-fed ditches in a riparian peatland. Sci. Total Environ. 332, 109-122.

SCHOLZ, M., and XU, J. (2002). Performance comparison of experimental constructed wetlands with different filter media and macrophytes treating industrial wastewater contaminated with lead and copper. Bioresource Technol. 83, 71-79. 
SCHOLZ, M., and ZETTEL, S. (2004). Storm water quality associated with a full silt trap discharging into urban watercourses. J. Ch. Inst. Water Environ. Manage. 18, 226-229.

SCHOLZ, M., HÖHN, P., and MINALL, R. (2002). Mature experimental constructed wetlands treating urban water receiving high metal loads. Biotechnol. Prog. 18, 1257-1264.

TCHOBANOGLOUS, G., BURTON, F.L., and STENSEL, H.D. (2003). Wastewater Engineering: Treatment and Reuse, 4th ed., revised. New York: Metcalf \& Eddy Inc. and McGraw Hill.

VYMAZAL, J. (2002). The use of sub-surface constructed wetlands for wastewater treatment in the Czech Republic: 10 years experience. Ecol. Eng. 18, 633-646.
VYMAZAL, J., and KRASA, P. (2003). Distribution of Mn, $\mathrm{Al}, \mathrm{Cu}$ and $\mathrm{Zn}$ in a constructed wetland receiving municipal sewage. Water Sci. Technol. 48, 299-305.

WIESSNER, A., KAPPELMEYER, U., KUSCHK, P., and KASTNER, M. (2004). Influence of the redox condition dynamics on the removal efficiency of a laboratory-scale constructed wetland. Water Res. 39, 248-256.

WOOD, T.S., and SHELLEY, M.L. 1999. A dynamic model of bioavailability of metals in constructed wetland sediments. Ecol. Eng. 12, 231-252.

ZHAO, Y.Q., SUN, G., and ALLEN S.J. (2004). Purification capacity of a highly loaded laboratory scale tidal flow reed bed system with effluent recirculation. Sci. Total Environ. 330, $1-18$ 
LEE

QU1

Fig. 2 was mailed back yesterday. Fig. OK? 